\title{
Analysis of Underpressured Reservoirs for Waste Disposal
}

\author{
J. J. Jiao', C. Zheng ${ }^{2}$ and R.J.-C. Hennet ${ }^{3}$
}

\begin{abstract}
Underpressured reservoirs are known to exist in sedimentary basins throughout the world and are common in North America. Deep-well injection of hazardous liquid wastes into underpressured reservoirs has been mentioned as a safe means for waste disposal because of their tendency to contain fluids for long periods of time. In this study, a numerical model based on the geological setting of the Hugoton field in the southwestern United States is used to analyze the potential of underpressured reservoirs for safe disposal of liquid wastes. The factors controlling the pressure buildup and disposal volume are evaluated by studying the sensitivities of the numerical model to various flow and reservoir parameters. The safe disposal volume on a per-well basis is estimated under the restrictive conditions that underpressurization persists during and after injection, and that the migration of the waste is restricted to prevent contamination of the overlying aquifers for an operationally permanent time period. This study demonstrates that the presence of the ultra-low permeability formation surrounding an underpressured reservoir makes it possible for the waste to be contained safely and permanently. Even if the pressure in the reservoir and the overlying formations rises to hydrostatic, possible upward migration of the contaminants is likely to be dominated by molecular diffusion across the ultra-low permeability formation and thus would be too slow to be of significance at human time scale.
\end{abstract}

Résumé: On sait qu'il existe dans les bassins sédimentaires des réservoirs en dépression et qu'ils sont communs en Amérique du Nord. L'injection en puits profonds de déchets liquides dangereux dans des réservoirs en dépression est considérée comme un moyen sûr de stockage de déchets, parce qu'ils ont tendance à conserver les fluides durant des temps prolongés. Dans cette étude, un modèle numérique, s'appuyant sur la configuration géologique du site de Hugoton dans le sud-ouest des États-Unis, est utilisé pour analyser le potentiel de réservoirs en dépression pour le stockage en toute sécurité de déchets liquides. Les facteurs qui contrôlent la montée en pression et le volume de stockage sont évalués à partir de l'étude de sensibilité du modèle numérique aux différents paramètres de l'écoulement et du réservoir.

Le volume unitaire par puits de déchets à stocker en toute sécurité est estimé à partir des conditions restrictives que la dépression se maintient pendant et après l'injection, et que la migration des déchets est limitée pour éviter la contamination des aquifères supérieurs définitivement. Cette étude montre que la présence de formations à très faible perméabilité autour du réservoir en dépression rend possible le stockage de déchets en toute sécurité et de façon permanente. Même si la pression dans le réservoir et dans les formations sus-jacentes atteint la pression hydrostatique, l'éventuelle migration vers le haut des polluants doit être vraisemblablement dominée par la diffusion moléculaire au travers de la formation à très faible perméabilité et, par conséquent, doit être trop lente pour être observable à l'échelle humaine.

Resumen: Los embalses subterráneos naturales a baja presión son comunes en cuencas sedimentarias en todo el mundo y, en particular, en Norte América. La inyección profunda de residuos líquidos peligrosos a este tipo de embalses subterráneos se ha considerado como una alternativa segura para el almacenamiento de los residuos, por su tendencia a contener fluidos durante largos periodos de tiempo. En este estudio se usa un modelo numérico basado en la configuración geológica de la zona de Hugoton, al oeste de los Estados Unidos de América, para analizar la potencial utilización de estos embalses como lugares de vertido de residuos líquidos. Los factores que controlan los incrementos de presiones y el volumen de vertido admisible se evalúan analizando la sensibilidad del modelo a varios parámetros de flujo. El volumen de vertido por pozo que puede considerarse como seguro se estima bajo la condición restrictiva que las bajas presiones persisten durante y después de la inyección, y que la migración del residuo está restringida para prevenir la contaminación de los acuíferos sobreyacentes para un periodo de operación permanente. Este estudio demuestra que la presencia de la formación con permeabilidad ultra-baja que rodea estas formaciones hace posible que el residuo quede contenido de manera segura y permanente. Incluso en el caso que la presión, tanto en el embalse como en las formaciones superiores, creciera hasta el valor hidrostático, la posible migración de contaminantes hacia la superficie estaría dominada seguramente por la difusión molecular a través de la formación de menor permeabilidad $y$, por tanto, sería demasiado lenta para ser significante a escalas de tiempo humanas.

'Department of Earth Sciences, University of Hong Kong, Pokfulam Road, P.R. China.

${ }^{2}$ Department of Geology, University of Alabama, Tuscaloosa, AL 35487, USA.

${ }^{3}$ S.S. Papadopulos \& Associates, Inc., 7944 Wisconsin Ave., Bethesda, MD 20814, USA.

Hydrogeology Journal, v. 5, no. 3, 1997 


\section{Introduction}

Disposal of toxic organic, inorganic, and radioactive liquid wastes is a major environmental and social problem with enormous economic implications in the United States and abroad (LaMoreaux and Vrba, 1990). Deep-well injection has been commonly used as an economical way to dispose of liquid wastes. However, this approach has associated risks that could potentially have serious environmental consequences. For example, injected waste fluids can migrate or displace fluids from the intended disposal repositories and cause widespread groundwater contamination.

Underpressured reservoirs, or fluid compartments as referred to in the petroleum literature, are known to exist in sedimentary basins throughout the world and are common in North America (e.g., Dickey and Cox, 1977; Bradley, 1985; Hunt, 1990; Neuzil, 1995; Bradley and Powley, 1995). Examples of some basins with underpressured reservoirs include the Western Canada basin in central Alberta, Canada, and the Denver basin in the United States (Hunt, 1990). A reservoir is underpressured when the pore fluid pressure is below the normal hydrostatic pressure for the depth considered, as illustrated schematically in Figure 1. Although some controversy and uncertainty still exist on the mechanisms of underpressurization in this kind of reservoir, underpressured reservoirs are usually surrounded by natural, ultra-low permeability formations, such as shales and evaporites, that keep the reservoirs effectively isolated from the surrounding normally (i.e., hydrostatically) pressured formations (Bradley and Powley, 1995; Neuzil, 1995; Ortoleva, 1995). The ultralow permeability formations of this type have also been commonly referred to as "seals" in the petroleum literature (Bradley, 1985; Hunt, 1990).

Underpressured reservoirs surrounded by ultra-low permeability formations may represent safer repositories for toxic liquid wastes than normally pressured or overpressured reservoirs (Bradley, 1985). Waste fluids injected into a deep, underpressured zone would remain there as long as the pressure buildup due to injection and various geochemical reactions does not exceed the normal pressure. It would be difficult for the injected waste fluids to escape from the underpressured repositories because such repositories act as sinks for fluids in the subsurface. Even if the ultra-low permeability formations are disturbed by drilling or tectonic movement, there would be no tendency to force the liquid wastes to escape from the underpressured zone. Given the large number of underpressured reservoirs, coupled with their enormous sizes (Hunt, 1990; Bradley and Powley, 1995), the idea of utilizing underpressured reservoirs for safe, permanent disposal of hazardous wastes is attractive indeed, and deserves to be studied in greater detail.

Although subnormal-pressure phenomena in geological formations have been widely observed, some controversy exists on how subnormal pressure is generated and maintained. The underpressured reservoirs have been attributed to 1) hydraulic flow phenomena, such as ultra-low permeability formations (Bradley, 1985; Bradley and Powley, 1995) and regional hydrodynamics (Belitz and Bredehoeft, 1986; Senger
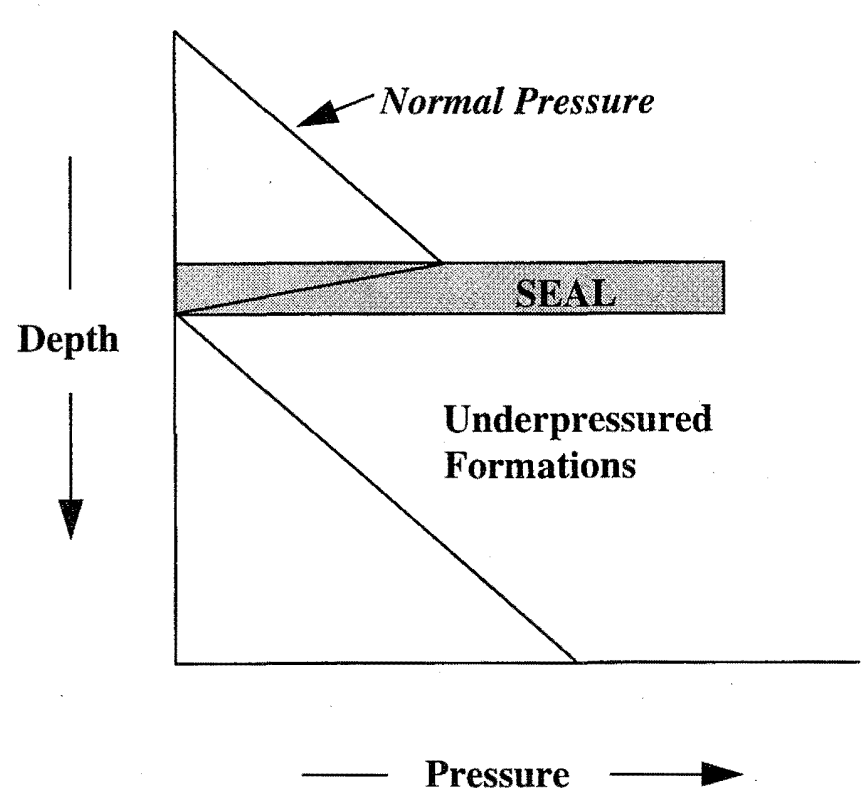

Figure 1. Diagram of underpressured formations, showing distribution of pressure with depth. "Seal" refers to a formation with ultra-low permeability (after Hunt, 1990).

and Fogg, 1987; Belitz and Bredehoeft, 1988); 2) geological processes, such as erosion of formations (Neuzil and Pollock, 1983; Corbet and Bethke, 1992) and burial of gas-saturated reservoirs (Russell, 1972; Barker, 1987); and 3) physicochemical processes, such as osmosis and fluid uptake in diagenetic reactions (Neuzil, 1986; Ortoleva et al., 1995). Although the reasons for subnormal pressure in a particular reservoir may not be unique and the explanations by various researchers may be controversial, it is believed that an abrupt and large decline in pressure over a small vertical interval and maintenance of significant anomalous pressure over geological times must involve a formation with an extremely low permeability. Comprehensive reviews on abnormal pressures from different perspectives occur in Neuzil (1995), Bradley and Powley (1995), and Ortoleva et al. (1995).

Some researchers in petroleum engineering are very confident about the existence of underpressured reservoirs that are well-sealed and totally isolated from surrounding formations (Russell, 1972; Bradley and Powley, 1995), whereas some hydrogeologists argue that no properly tested geologic media have proved to be entirely impermeable (Neuzil, 1986) and that slow transient flow always occurs between the underpressured reservoir and neighboring formations (Belitz and Bredehoeft, 1986). It is generally recognized, however, that the permeability of the so-called seal formations surrounding the underpressured reservoirs can be so low that the transient flow response times may be comparable with geologic time scales (Bredehoeft and Hanshaw, 1968; Neuzil, 1986; Ortoleva, 1995). If an underpressured reservoir is surrounded by such an ultra-low permeability formation, the subnormal fluid pressure in the reservoir can be maintained on the scale of hundreds of thousands to millions of years, and 
thus may be considered effectively permanent for disposal of most liquid wastes.

Abnormal pressure phenomena in geological formations have been generally recognized, but most studies have focused on formations with abnormally high pressures formations (e.g., Bredehoeft and Hanshaw, 1968; Keith and Rimstidt, 1985; Ortoleva, 1995). Many fewer studies exist on reservoirs with abnormally low pressures, especially for the purpose of waste disposal from a quantitative hydrogeologic perspective. Senger and Fogg (1987) were probably the first to simulate numerically the regional underpressuring with the aim of evaluating suitability for waste disposal, but their study concentrates on the suitability of using the evaporite aquitard in the Palo Duro Basin, Texas, for disposal of high-level nuclear wastes. As for using underpressured reservoirs for storing liquid wastes, little work has been done since Bradley (1985) presented an expression for estimating the maximum disposal volume based on a single-well model.

The objective of this paper is to explore the feasibility of liquid waste disposal in a hypothetical underpressured reservoir that has a geological setting similar to that of the Hugoton field in southwestern United States. First, the geology of the Hugoton field is briefly examined. Then, the vertical hydraulic head and concentration distributions in response to potential waste injection are investigated using a version of the heat and solute transport code HST3D (Kipp, 1987). An attempt is made to estimate the maximum permeability of the "seal" formation surrounding the underpressured reservoir. The sensitivities of the model to flow and transport parameters are analyzed to gain physical insights into the factors controlling the pressure buildup and disposal volume. Finally, the maximum safe disposal volume is estimated under the restrictive conditions that underpressurization persists after injection, and that the migration of the waste is contained to prevent contamination of the neighboring aquifers for an operationally permanent time period.

\section{Description of The Hugoton Field}

\section{Geology}

The Hugoton field underlies approximately $16,000 \mathrm{~km}^{2}$ in three states, as shown in Figure 2. The principal gas production zones in the field are the limestone and dolomite formations of the Chase Group of Lower Permian age. As indicated by the geologic section of Figure 3, the structure of the field is that of a generally eastward-dipping homocline, the inclination of the beds increasing with depth. Therefore, the Wellington Shale becomes the eastern impermeable boundary. The sediments in the Chase Group are predominantly of organic origin throughout the greater part of the field, but they grade to increasing percentages of fine clastic materials toward the western edge. Red shale and siltstone are common in the western part of the field, and these form the western boundary of the field. The Hugoton field is terminated on the north, as on the west, by a marked decrease in the thickness and permeability of the carbonate units of the Chase Group. The regional uplift in the southern part of the basin resulted in truncation of the Chase Group. The granite rock becomes the

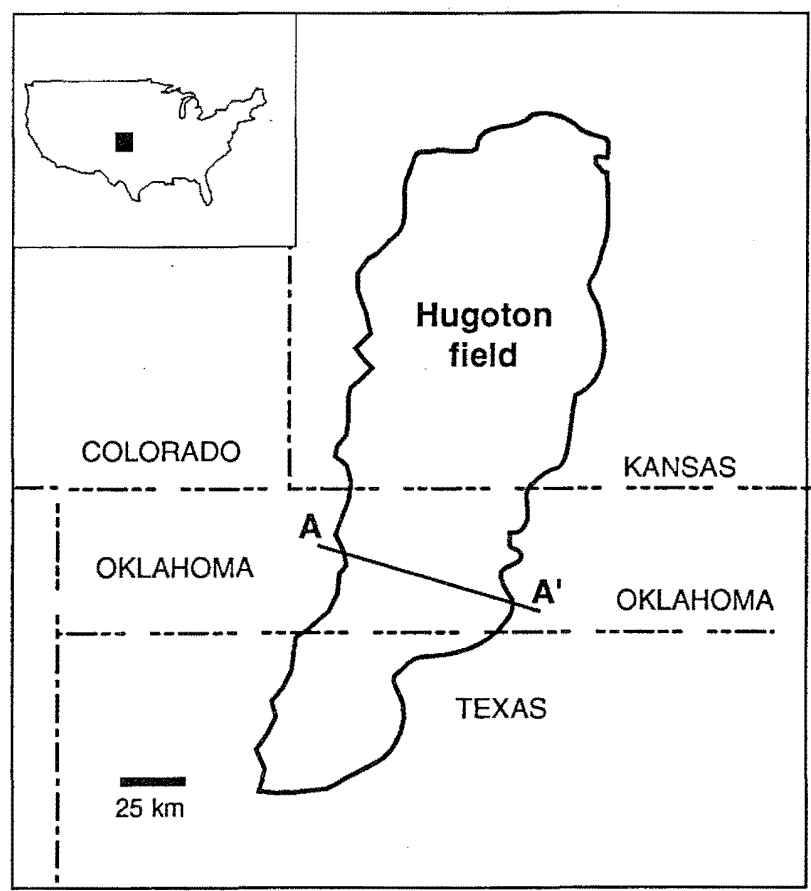

Figure 2. Location of the Hugoton field, central USA (modified from Ebbs et al., 1990).

southern impermeable boundary (Adler et al., 1971; Pippin, 1968).

The regional stratigraphy in the Hugoton field is presented in Garlough and Taylor (1941) and Pippin (1968). Among many geologic formations, only the three most important units for this analysis (Chase Group, Sumner Group, and Ogallala Formation) are described here.

The Chase Group is the major gas reservoir in the Hugoton field (Fig. 3). This group consists of approximately $107 \mathrm{~m}$ of interlayered carbonates, siliciclastics, and evaporites in the Guymon, Oklahoma, area (Siemers and Ahr, 1990). Based on detailed analysis of the reservoir facies, pore characteristics, and flow units of the Chase Group, Siemers and Ahr (1990) concluded that the interlayered carbonates and shaly layers form a regionally continuous, multilayered reservoir consisting of carbonate/siltstone flow units separated by shaly barriers, and that little vertical communication or crossflow occurs between the separate flow units. A similar conclusion was reached by Ebbs et al. (1990), who observed that replacement wells completed in different layers from the original oil production wells have significantly different shut-in pressures, indicating that the layers have poor vertical hydraulic connection.

Siemers and Ahr (1990) present some information on the permeability of the Chase reservoir, although no explanation is given on how it was obtained. The Chase reservoir is divided into three units, with permeability ranging from $1 \times 10^{-35}$ to $2 \times 10^{-14} \mathrm{~m}^{2}, 1 \times 10^{-16}$ to $3 \times 10^{-13} \mathrm{~m}^{2}$, and $4 \times 10^{-15}$ to $1.6 \times 10^{-14}$ $\mathrm{m}^{2}$, respectively. For discussions in this paper, the permeability of the reservoir is assumed to be $5 \times 10^{-13} \mathrm{~m}^{2}$. The influence 


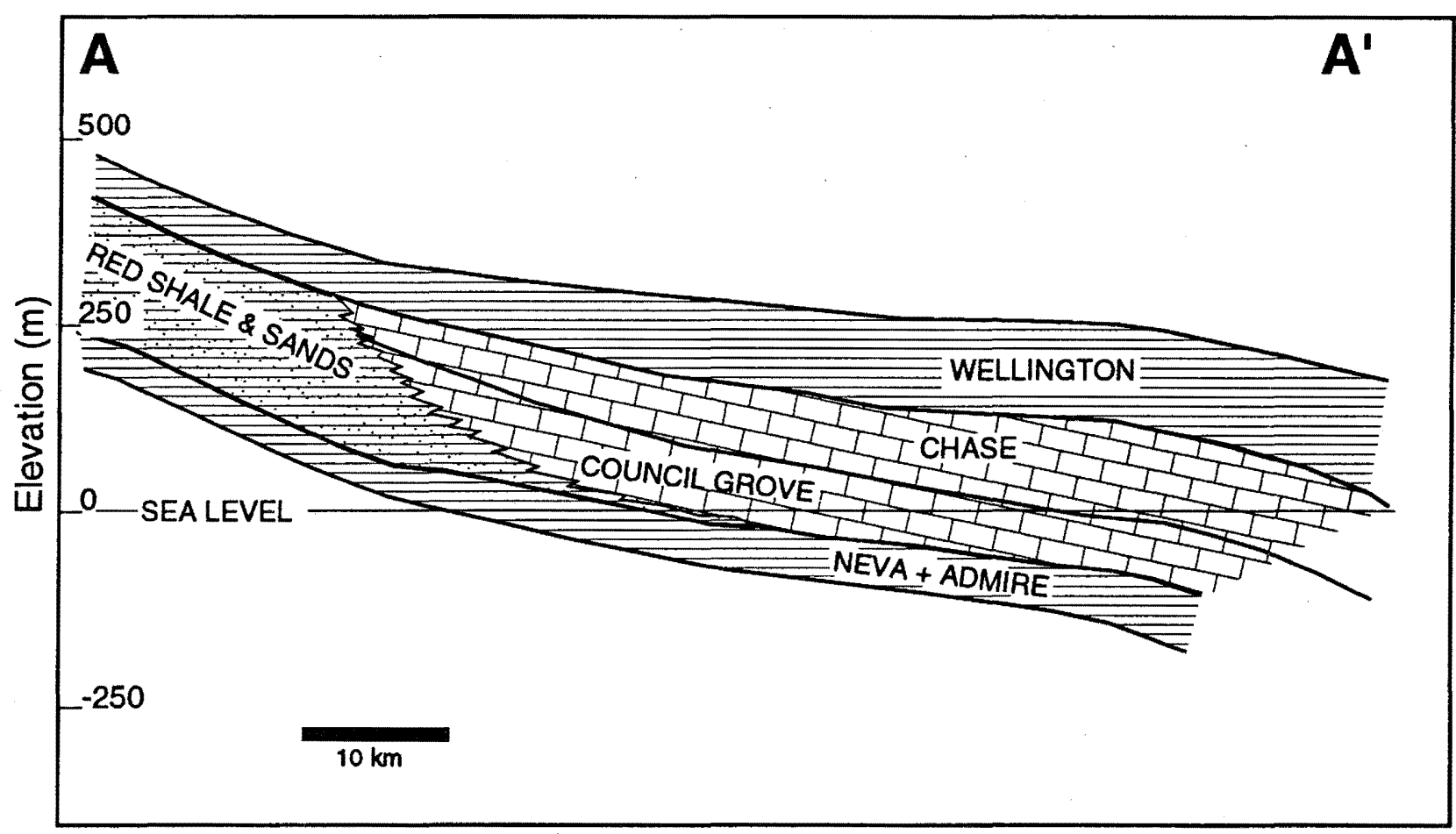

Figure 3. Geologic section across the Hugoton field (modified from Pippin, 1968). Line of section shown in Figure 2.

of the value of this parameter on injection is examined subsequently through sensitivity analysis.

The unit above the Chase Group is the Sumner Group, which is composed of shale, evaporite, anhydrite, and buff, finely crystalline dolomite. The Wellington Formation (shale and evaporite) makes up a little less than two-thirds of this group. The thickness of this formation is $61-107 \mathrm{~m}$. The permeability of evaporites ranges from $10^{-21}-10^{-17} \mathrm{~m}^{2}$ (Freeze and Cherry, 1979), but as in many other reservoirs, no directly measured information is available on the permeability of the shale of the Wellington Formation in the Hugoton field. For this analysis, the permeability of this formation is critical and is estimated from the available data.

The Ogallala Formation is the major shallow aquifer. It consists of unconsolidated or semiconsolidated sediments that are composed of discontinuous layers of sand, silt, clay, and gravel. The average saturated thickness is $120 \mathrm{~m}$ and the average permeability of the shallow aquifer is approximately $2 \times 10^{-11} \mathrm{~m}^{2}$ (DeVries and Kent, 1973).

Numerous geologic formations occur between the Sumner Group and the Ogallala Formations. These formations are filled with brine and consist of mostly shale, minor fined-grained sandstone, and finely crystalline dolomite. Detailed descriptions of these formations are in Garlough and Taylor (1941).

\section{Subnormal Pressure of the Chase Reservoir}

The Chase reservoir is underpressured and overlain by the Wellington Shale of ultra-low permeability. The first well in Hugoton was drilled in 1918 (Mason, 1968), and it soon was discovered that the reservoir was underpressured. In several decades since, no increase in the reservoir pressure has been observed. Instead, in many areas, because of oil and gas production, the reservoir pressure has been declining. The reservoir pressure in 1926 was $485 \mathrm{psi}\left(3.3 \times 10^{6} \mathrm{~Pa}\right)$, and in 1965 the pressure was $360 \mathrm{psi}\left(2.5 \times 10^{6} \mathrm{~Pa}\right)$ (Bradley; 1985). The recent pressure in an area in Guymon, Oklahoma, is 227 psi $\left(1.6 \times 10^{6} \mathrm{~Pa}\right)$ (Ebbs et al., 1990).

Many pressure-depth plots show that the reservoir is underpressured. As an example, Figure 4 shows a pressuredepth relation compiled from drill-stem test data in Sherman County, Texas (D.E. Powley, written comm.). The pressure declines abruptly at the depth of about $3,000 \mathrm{ft}(914 \mathrm{~m})$, which coincides with the location of the Wellington Shale in this area. The underpressured Chase reservoir would be a potential host reservoir for waste injection and is the object of this study.

\section{A Simplified Model for Waste Disposal}

For this study, the vertical geological section is simplified into four zones: 1) the reservoir (the Chase Group); 2) the "seal" formation of ultra-low permeability (the Wellington Shale); 3) the shallow aquifer (the Ogallala Formation); and 4) a transition zone between the "seal" formation and the shallow aquifer. The ultra-low permeability formation, the reservoir, and the shallow aquifer are each assumed to be approximately $100 \mathrm{~m}$ thick and the transition zone approximately $700 \mathrm{~m}$ thick. For simplicity, it is assumed that the formations are filled with brine only. The density is assumed to be $1.075 \mathrm{~g} / \mathrm{cm}^{3}$, leading to a normal hydrostatic gradient of $0.465 \mathrm{psi} / \mathrm{ft}(1 \times 104 \mathrm{~Pa} / \mathrm{m})$ (Bradley, 1985). The initial pressure distribution is shown in Figure 5 and is largely based on the information from Bradley 


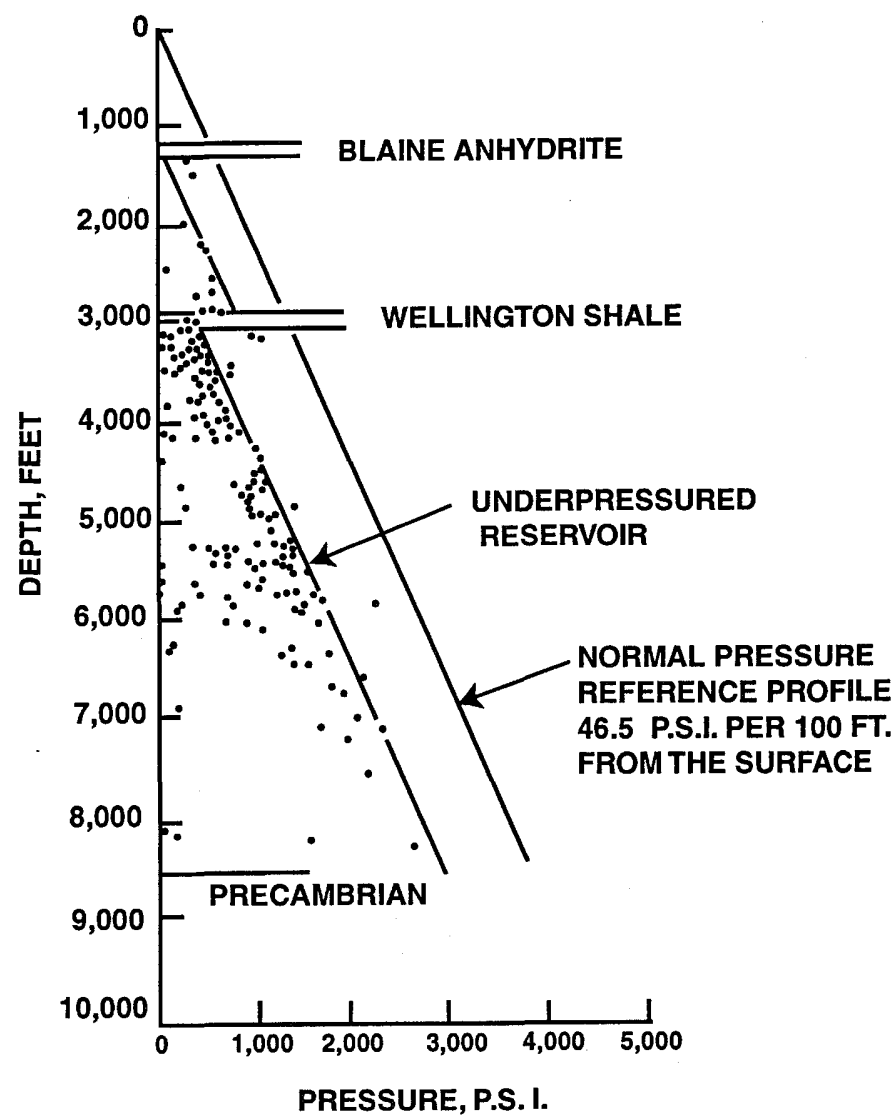

Figure 4. Relation between pressure and depth, Sherman County, Texas (D.E. Powley, written commun.).

(1985). The problem to be addressed is simplified as: How much waste can be injected into the underpressured reservoir subject to the constraints that the underpressurization persists and the shallow aquifer is not contaminated after injection?

Wells in the Hugoton field are patterned on a mile grid. That is, one well represents a fixed area approximately equivalent to a circular area with a radius of $0.9 \mathrm{~km}$. The single-well model similar to that of Bradley (1985) is also used in this study. For simplicity, it is assumed that the reservoir represented in the single-well model has a radius of $1 \mathrm{~km}$. In order to focus on the physical processes, a non-reactive liquid waste is assumed for this study.

\section{Storage Capacity of Confined Reservoirs}

In the state of equilibrium, the total stress due to the weight of overlying rock and water acting downward on the reservoir is balanced by the effective stress of the reservoir matrix and the fluid pressure of the water in the reservoir (Freeze and Cherry, 1979). When water is injected into a reservoir, the fluid pressure $p$, or hydraulic head $h(h=Z+p / \rho g$, where $Z$ is the elevation potential; $\rho$ is the fluid density; and $g$ is the gravitational acceleration constant), is increased and the effective stress is decreased. Decreasing effective stress leads to the expansion of the matrix, and the increasing fluid

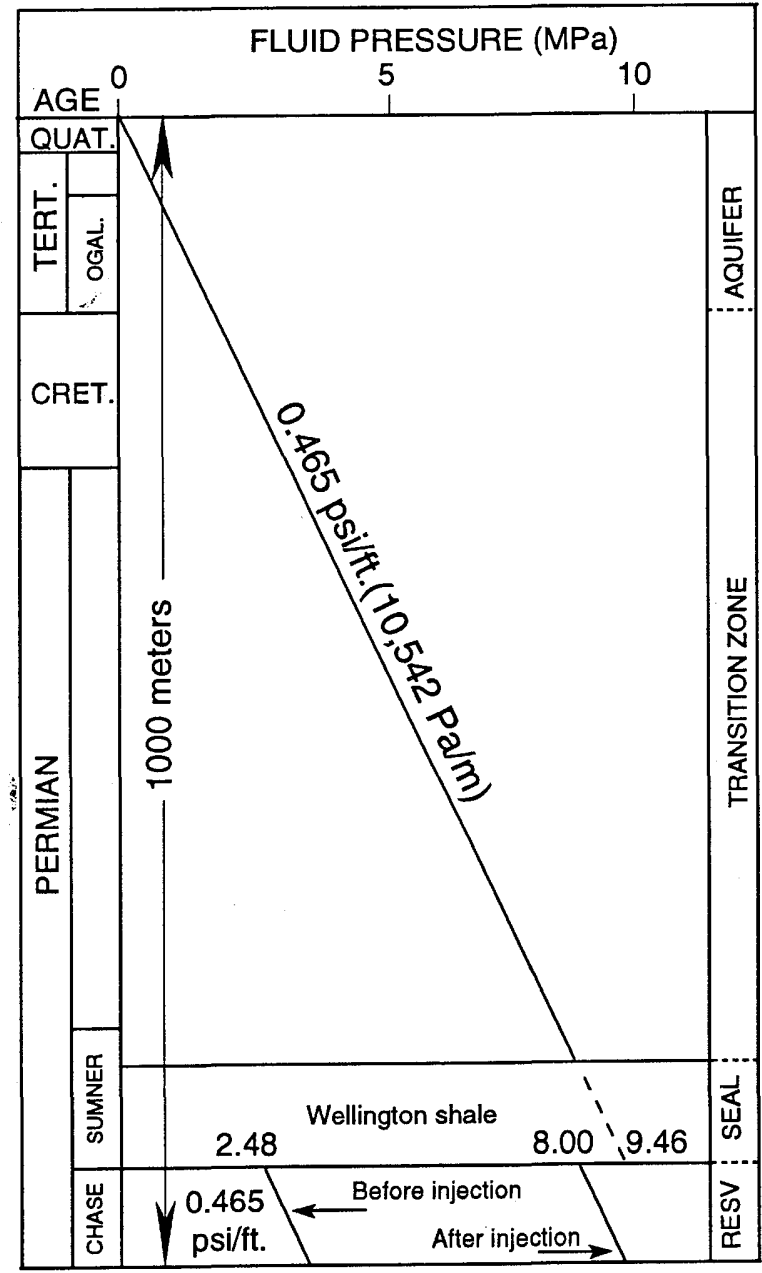

Figure 5. Relation between pressure and depth, Hugoton field, Oklahoma (modified from Bradley, 1985).

pressure leads to the contraction of the water. The first of these mechanisms is controlled by the matrix compressibility $\beta_{m}$, and the second by the fluid compressibility $\beta_{w}$. For a unit volume of reservoir, when the hydraulic head is increased by a unit, the amount of water stored into the reservoir can be calculated as:

$$
S_{s}=\gamma\left(\beta_{m}+n \beta_{w}\right)
$$

where $\gamma$ is the weight density of the water, $n$ the porosity, and $S_{s}$ the specific storage. For a reservoir with a thickness $M$, when the hydraulic head is increased by a unit over a unit area, the change in water stored is:

$$
S=M \gamma\left(\beta_{m}+n \beta_{w}\right)
$$

where $S$ is the storativity. If the reservoir has an area $A$ and the hydraulic head is uniformly increased by $\Delta h$, the water volume stored can be calculated as: 


$$
\begin{aligned}
V & =A S \Delta h \\
& =\frac{A S \Delta p}{\gamma} \\
& =\frac{A M \gamma\left(\beta_{m}+n \beta_{w}\right) \Delta p}{\gamma} \\
& =A M\left(\beta_{m}+n \beta_{w}\right) \Delta p
\end{aligned}
$$

Equation (3) shows that the theoretical disposal volume depends only on the area, thickness, the storativity, and the maximum allowable pressure buildup of the reservoir. The possible disposal volume can be roughly estimated. The porosity for the Chase reservoir is about 14 percent (Mason, 1968). The liquid compressibility is generally of the value of $4.4 \times 10^{-10} / \mathrm{Pa}$ (Bradley, 1985). No measured data exist for the matrix compressibility. Ferran (1973) used the value of $1.1 \mathrm{x}$ $10^{-9} / \mathrm{Pa}$ as the matrix compressibility to investigate the abnormal pressures in this area and the same value is used here. For a reservoir with a radius of $1,000 \mathrm{~m}$ and a thickness of $100 \mathrm{~m}$, suppose that the maximum allowable pressure limit for safe disposal in this reservoir is $8.00 \times 10^{6} \mathrm{~Pa}$ (Fig. 5), which is substantially below the normal hydrostatic pressure of $9.46 \times 10^{6} \mathrm{~Pa}$. If liquid wastes are injected into the reservoir to raise the pressure from $2.48 \times 10^{6} \mathrm{~Pa}$ to $8.00 \times 10^{6} \mathrm{~Pa}$, the amount of liquid wastes injected, calculated using equation (3), is $1.98 \times 10^{6} \mathrm{~m}^{3}$.

\section{Numerical Simulation Study}

HST3D, a numerical code for simulation of heat and solute transport in three-dimensional groundwater flow system (Kipp, 1987), is used for this study. The model area is represented by a cylindrical-coordinate system, with an interior radius of $1 \mathrm{~m}$ and an exterior radius of $1,000 \mathrm{~m}$. The radial dimension is divided into 29 intervals that increase logarithmically, and the vertical dimension is divided into 19 intervals. The detailed finite-difference mesh for the numerical model is shown in Figure 6. For simplicity, the temperature change over depth is neglected and the system is assumed to be isothermal. The temperature of the liquid (both waste and the host water) is assumed to be $20^{\circ} \mathrm{C}$. The molecular diffusion coefficient is taken as $1 \times 10^{-10} \mathrm{~m}^{2} / \mathrm{d}$. The values of formation thickness, porosity, horizontal permeability, and longitudinal dispersivity used in the model are summarized in Table 1. It is assumed that for each model layer the vertical permeability and transverse dispersivity are one-tenth of the horizontal permeability and longitudinal dispersivity. The permeability of the "seal" formation representing the Wellington Shale is a key factor and the method of estimating its value is discussed in the following section.

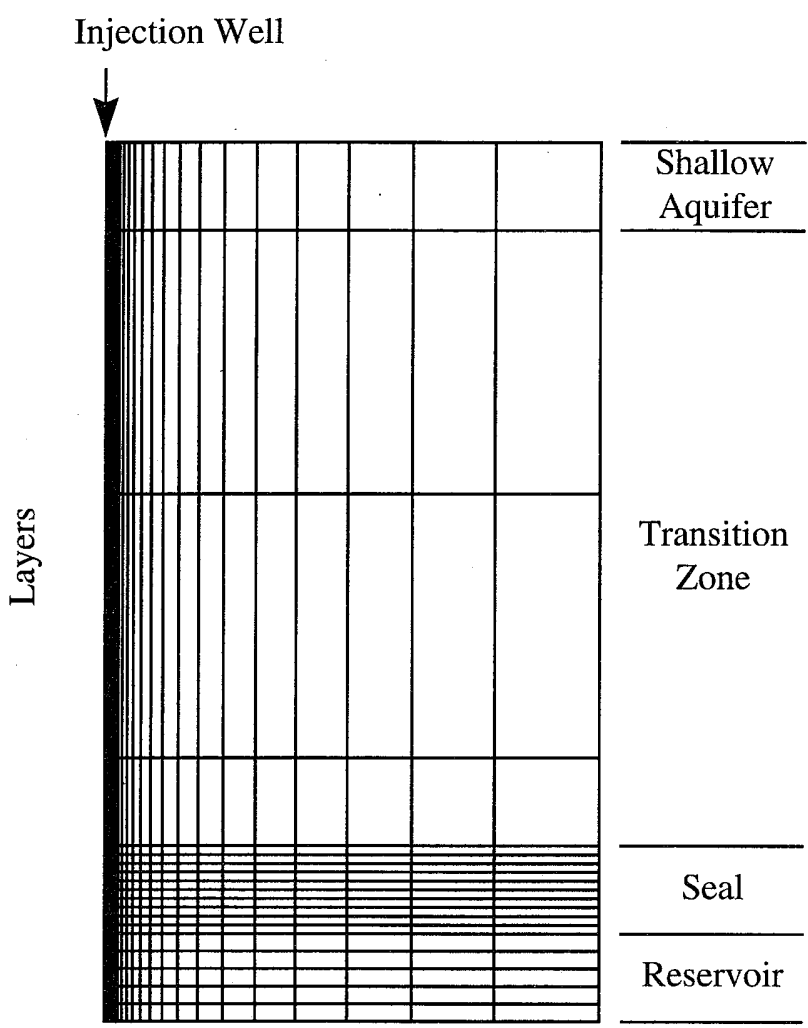

Columns

Figure 6. Finite-difference mesh for the numerical model of waste injection into an idealized underpressured

\begin{tabular}{|c|c|c|c|c|}
\hline Zone & $\begin{array}{l}\text { Thick- } \\
\text { ness } \\
(\mathbf{m})\end{array}$ & $\begin{array}{l}\text { Por } \\
\text { osity }\end{array}$ & $\begin{array}{l}\text { Hori- } \\
\text { zontal } \\
\text { perme- } \\
\text { ability } \\
\left(\mathrm{m}^{2}\right)\end{array}$ & $\begin{array}{l}\text { Longi } \\
\text { tudinal } \\
\text { disper- } \\
\text { sivity } \\
(\mathrm{m})\end{array}$ \\
\hline Aquifer & 100 & 0.30 & $2 \times 10^{-11}$ & 1.0 \\
\hline Transition & 700 & 0.20 & $1 \times 10^{-17}$ & 1.0 \\
\hline Seal & 100 & 0.10 & $1 \times 10^{-20}$ & 0.1 \\
\hline Reservoir & 100 & 0.14 & $5 \times 10^{-13}$ & 1.0 \\
\hline
\end{tabular}
reservoir. "Seal" refers to a formation of ultra-low permeability.

Table 1. Parameters used in the numerical model.

\section{Maximum Permeability of the Wellington Formation}

The Chase reservoir in the Hugoton field was observed as underpressured many decades ago. It can be reasonably assumed that the permeability of the Wellington Shale is sufficiently low such that no significant pressure change has occurred in at least the last 100 years. The permeability value 
that leads to insignificant pressure changes is assumed to be the maximum permeability of the Wellington Formation.

For simplicity, the formations above the Wellington Shale are treated as a single aquifer, with a horizontal permeability of $2.0 \times 10^{-11} \mathrm{~m}^{2}$. Starting from the initial pressure distribution shown in Figure 5, the HST3D code was run for various values of the seal permeability $k$. The simulated vertical-head distributions are shown in Figure 7. The head in the transition zone does not change significantly with depth; therefore, only the head in the first $600 \mathrm{~m}$ from the bottom of the reservoir is shown. When $k=1 \times 10^{-20} \mathrm{~m}^{2}$ the head change over 100 years (denoted by the line with triangles) is insignificant and is indistinguishable from the initial head (denoted by a continuous line). When $k$ is increased to $1 \times 10^{-19} \mathrm{~m}^{2}$, the head changes by $2 \mathrm{~m}$ over 100 years, as denoted by diamonds in Figure 7. When $k$ is greater than $1 \times 10^{-18} \mathrm{~m}^{2}$, the head changes significantly. From this experiment, it can be reasonably assumed that the maximum horizontal permeability of the Wellington Shale is about $1 \times 10^{-20} \mathrm{~m}^{2}$.

In the transition zone between the shale and the aquifer, the permeability is assumed to be larger than that of the seal formation and much smaller than that of the shallow aquifer. In the following discussions, the value of $1 \times 10^{-17} \mathrm{~m}^{2}$ it is assigned.

\section{Sensitivity Analysis}

The volume of liquid waste that can be safely injected into a reservoir depends not only on its size and storativity for a given pressure limit (see equation 3 ), but also the buildup of pressure over time during the injection process. The pressure may build up so quickly near the injection well that it may be higher than the hydrostatic pressure limit before the potential maximum volume is reached. For the purpose of safety, the reservoir should always be underpressured during the entire injection period so that no side effect, such as hydraulic fracturing and breach of the upper ultra-low permeability formation, will occur. Therefore, an understanding is needed of how the pressure changes during injection and what are the controlling factors for the pressure buildup. The sensitivity analysis was used to examine the influence of various parameters on pressure buildup.

\section{Basic sensitivity equations}

Sensitivity analysis is the study of a system's response to various model parameters. Mathematically, the sensitivity is a partial derivative that represents the change in head or pressure resulting from a change in a model parameter. For example, the sensitivity of head to permeability $k$ can be defined as:

$$
U_{k}=\frac{\partial h}{\partial k}
$$

A disadvantage of the sensitivities defined by equation (4) is that their magnitudes depend on the dimensions and units of the particular parameters. A normalized sensitivity can be defined as (McElwee, 1987):

$$
\hat{U}_{k}=k \frac{\partial h}{\partial k}=\frac{\partial h}{\left(\frac{\partial k}{k}\right)}
$$

The normalized sensitivity describes the influence of ratio changes in parameters. It has the unit of $h$. The sensitivity and normalized sensitivity of head or pressure to other parameters can be defined in the same way.

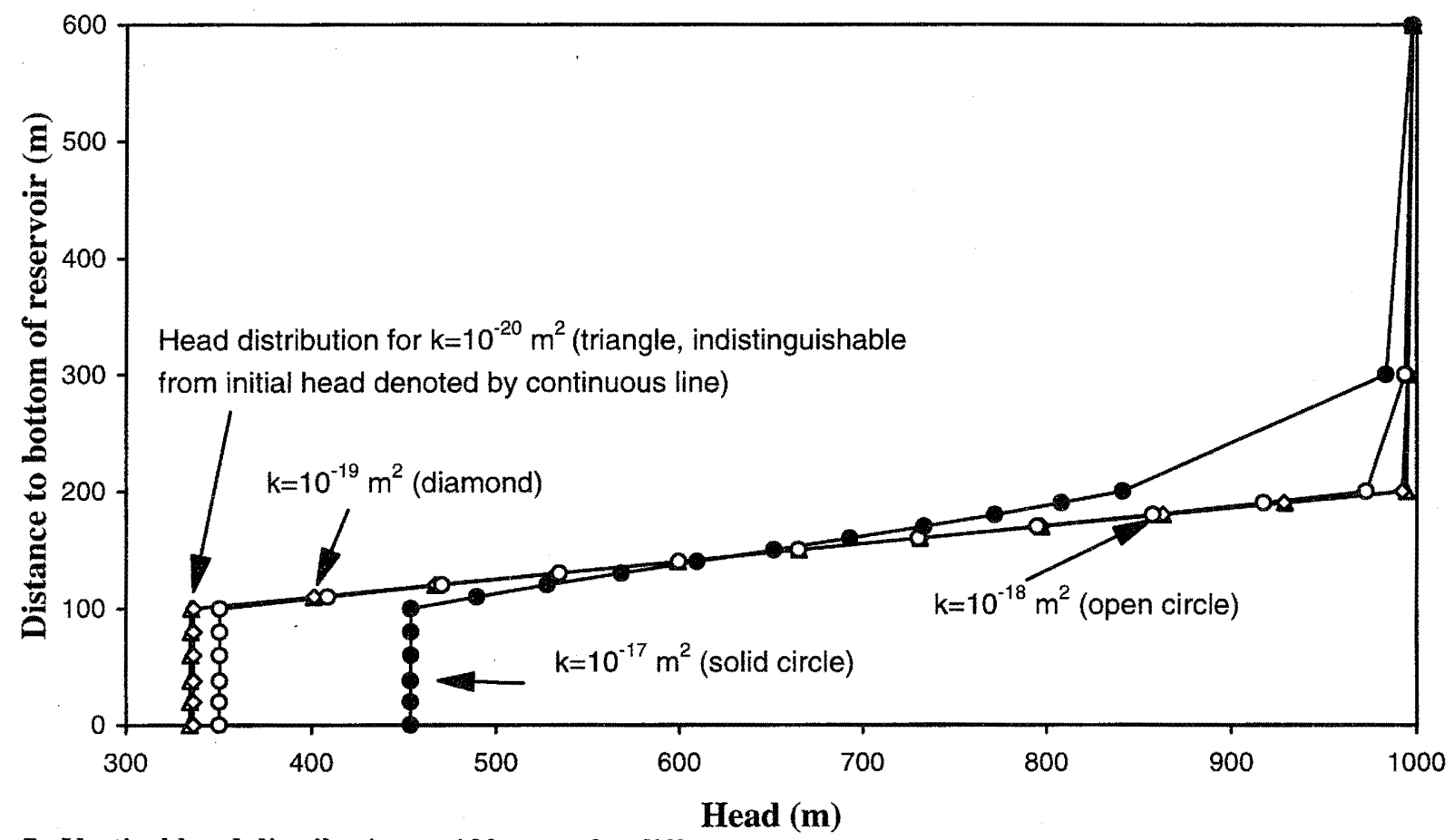

Figure 7. Vertical head distribution at 100 years for different reservoir permeabilities. 
Several methods exist for determining sensitivities of reservoir parameters; the easiest and most straightforward method is a finite-difference approximation (Beck and Arnold, 1977). For example, by running the numerical model twice with two slightly different values of permeability, the sensitivity is simply given by:

$$
U_{k} \approx \frac{\Delta h}{\Delta k}=\frac{(h(k+\Delta k)-h(k))}{\Delta k}
$$

For this study, sensitivities were evaluated using equation (6) and then converted into normalized values based on equation (5). The influence of parameters to the pressure near the injection well during the early period of injection is of main concern, so the sensitivity behavior of pressure at $r=5.3 \mathrm{~m}$ is examined. The hypothetical waste was injected at a rate of $1,210 \mathrm{~m}^{3} / \mathrm{d}$ for $40 \mathrm{~d}$.

\section{Sensitivities of pressure to aquifer and liquid properties}

Figure 8 shows the change of normalized sensitivity of pressure at $r=5.3 \mathrm{~m}$ to reservoir permeability, porosity, and compressibilities with time when the reservoir permeability is fixed at $k=5 \times 10^{-12} \mathrm{~m}^{2}$. The sensitivity to $k$ is the smallest and that to the matrix compressibility is the largest. The sensitivities of pressure to porosity and the water compressibility are almost identical. However, as shown in Figure 9, when $k=5 \times 10^{-14} \mathrm{~m}^{2}$, the sensitivity of pressure to $k$ becomes the largest. When the permeability is high (Fig. 8), the injected fluid can be easily transmitted laterally, and the pressure change depends mainly on the aquifer properties to store the waste. Therefore, the pressure is sensitive to parameters such as porosity, compressibilities of water and the matrix. When the permeability is low (Fig. 9), the aquifer has the capacity to accept injected fluids, but the ability of the aquifer to transmit them is very poor. In this case, the pressure is very sensitive to permeability.

The sensitivity of pressure to compressibility of matrix is larger than that to the compressibility of water, so the compressibility of matrix is more important in choosing a reservoir for waste disposal. The sensitivity curves also show that the influence of porosity and the liquid compressibility on pressure is almost indistinguishable, and the sensitivities of pressure to porosity and compressibilities are closely correlated. That is why these three parameters can be grouped into one parameter, i.e., the storativity.

The pressure is negatively sensitive to these parameters. This relationship means that increasing any of these parameters tends to slow down the buildup of the pressure and therefore to increase the disposal volume subject to the same pressure limit.

Figure 10 shows the sensitivity of pressure to density. The sensitivity to the density of the injected liquid is positive. The denser the waste, the higher the pressure near the observation well. The sensitivity is most significant when the front of the waste approaches the observation well, after which the sensitivity decreases with time. The sensitivity of pressure to the background liquid density is negative. This means that the pressure is lower when the density of the background fluid is

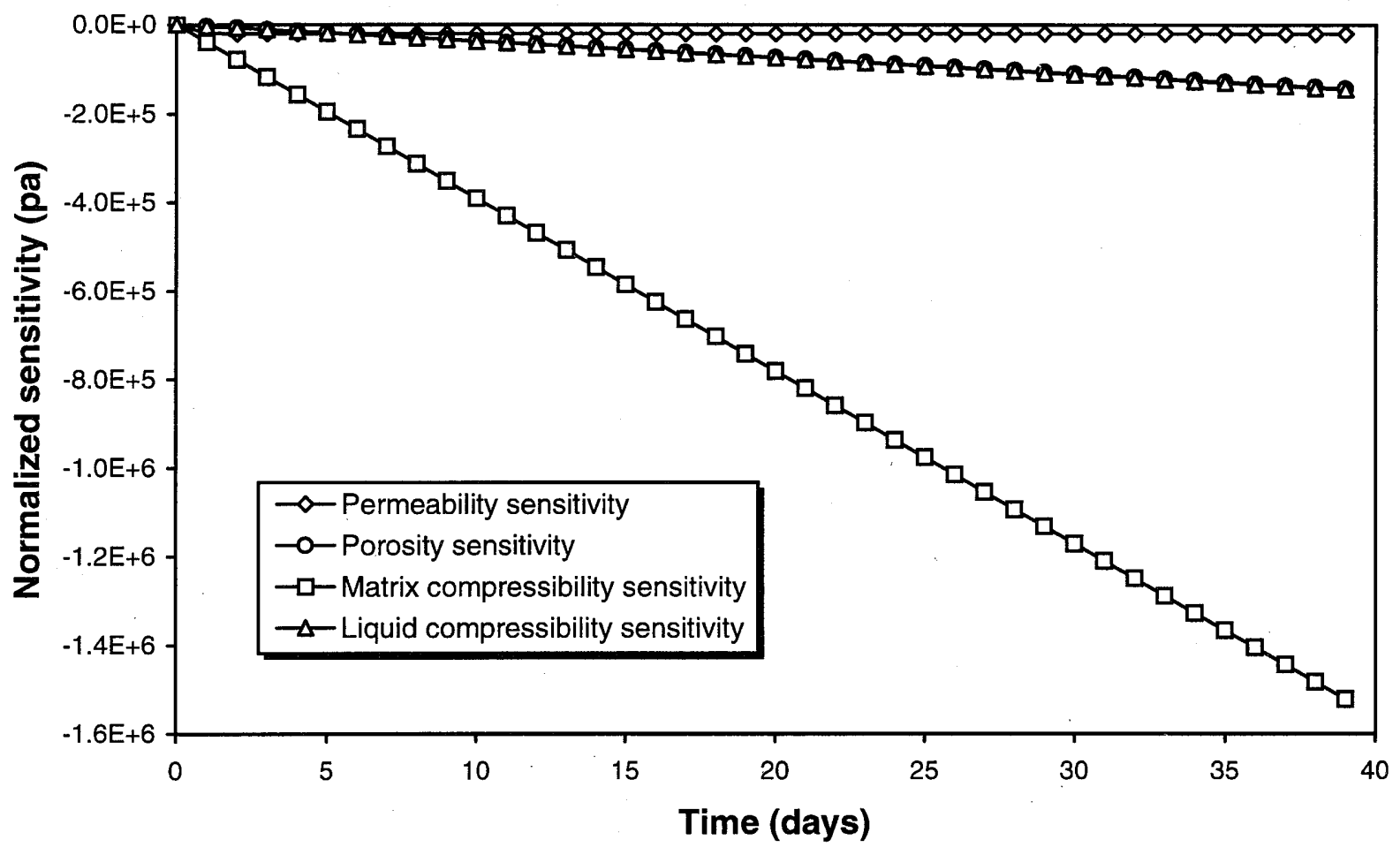

Figure 8. Relation between 1) normalized sensitivity of pressure to permeability, porosity, and matrix and liquid compressibilities, and 2) injection time; reservoir permeability $=5 \times 10^{-12} \mathrm{~m}^{2}$. 


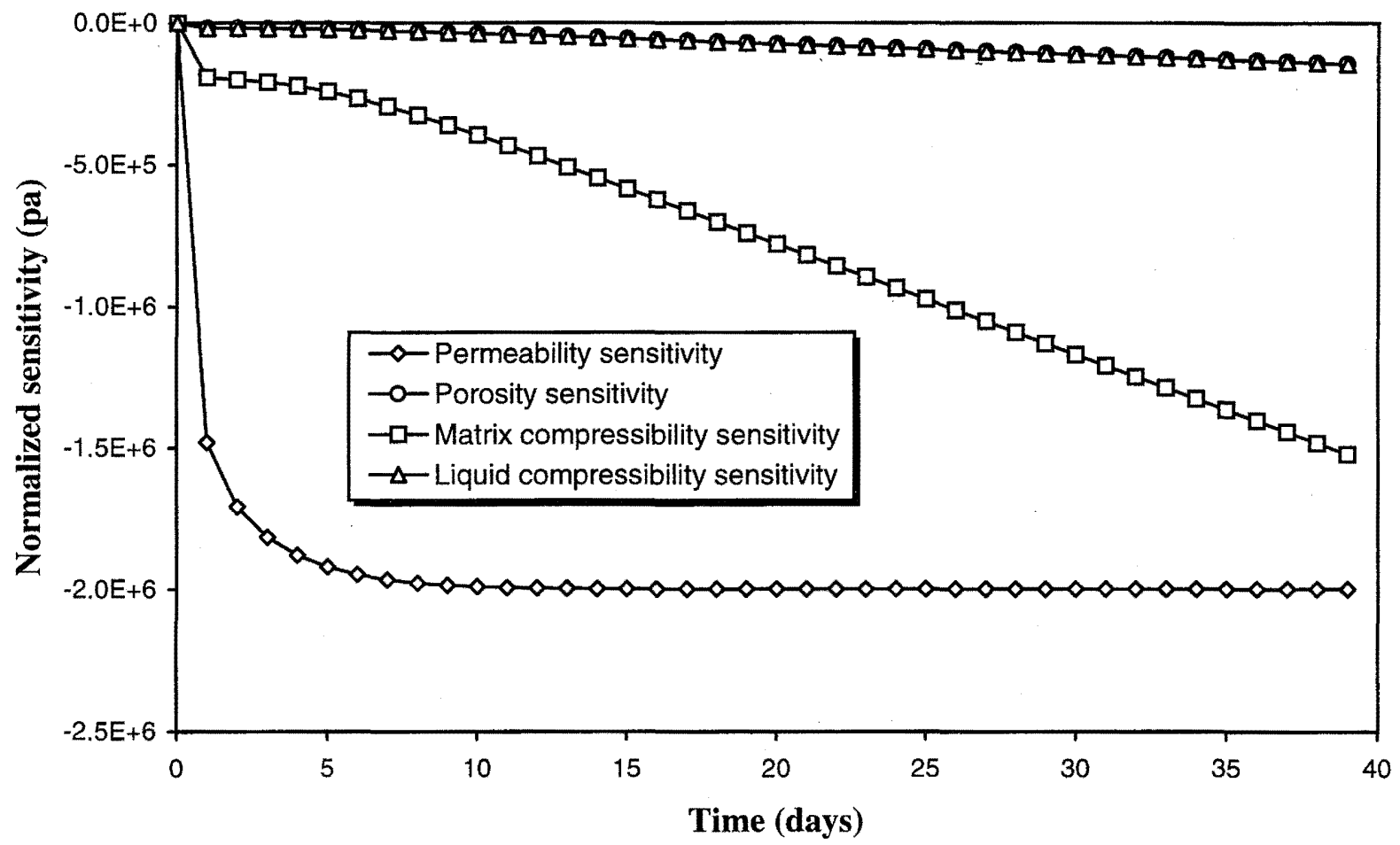

Figure 9. Relation between 1) normalized sensitivity of pressure to permeability, porosity, and matrix and liquid compressibilities, and 2) injection time; reservoir permeability $=5 \times 10^{-14} \mathrm{~m}^{2}$.

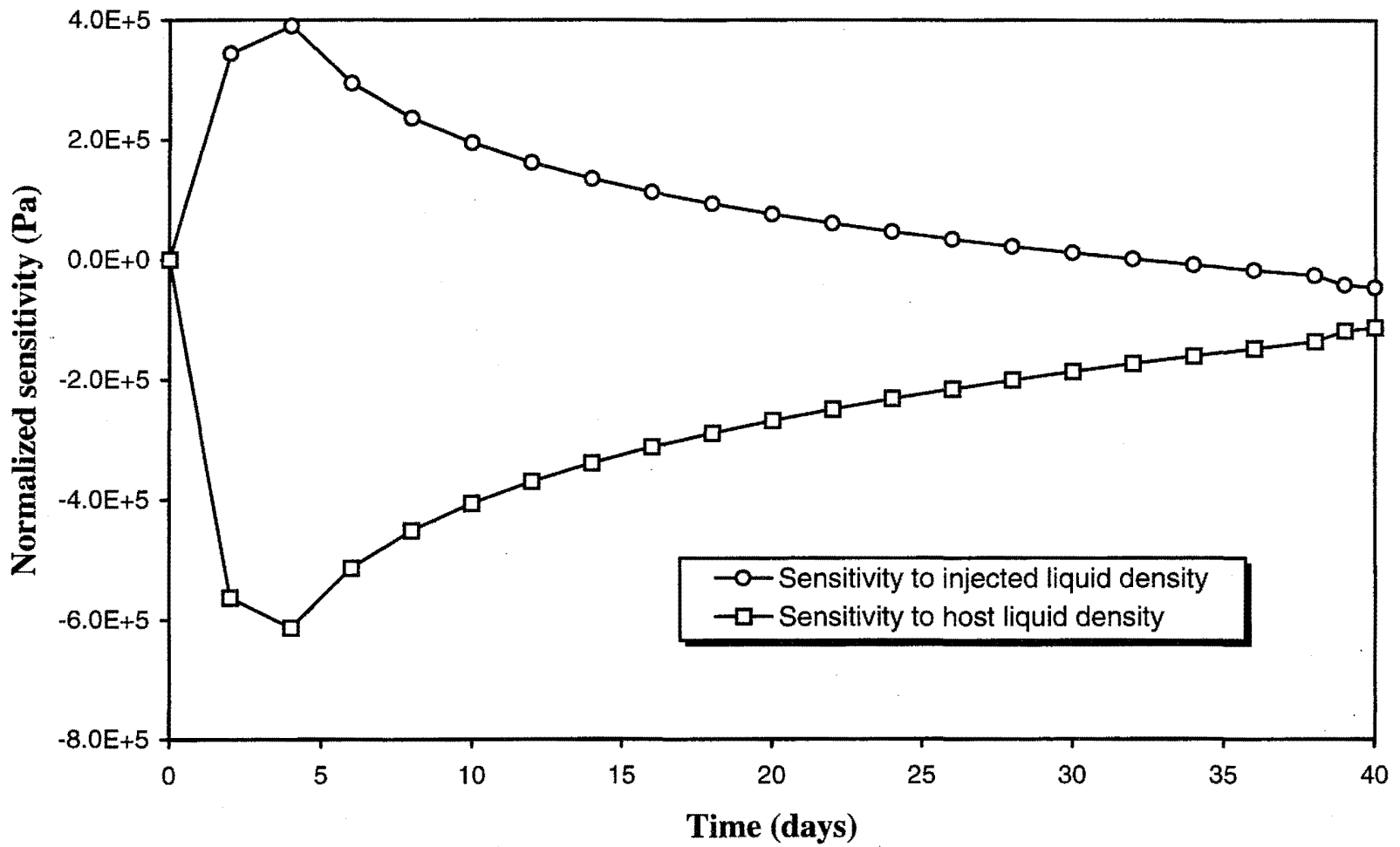

Figure 10. Relation between 1) normalized sensitivity of pressure to densities of injected and host liquids, and 2) injection time. 
larger, or the response of pressure in the reservoir to injection is less significant when the background liquid is more dense.

Figure 11 shows the variations with time of the sensitivity of pressure to viscosity for reservoir permeabilities $k=10^{-12} \mathrm{~m}^{2}$ and $k=10^{-14} \mathrm{~m}^{2}$. For low permeability, the flow is very slow and the sensitivity of viscosity is significant. When the permeability is higher, the sensitivity of viscosity is much less significant. Therefore, the viscosity is an important factor only when the permeability is small. The sensitivity of pressure to viscosity is always positive, i.e., the larger the viscosity, the lower the mobility of the liquid, and higher the pressure near the injection well.

\section{Summary of sensitivity analysis}

Permeability is the key parameter controlling pressure buildup around the injection well. The sensitivity behavior of many other parameters depends on the magnitude of permeability. For example, pressure is very sensitive to porosity and compressibilities only when permeability is high. Viscosity is a factor of concern only when permeability is low. For a reservoir of high permeability, the influence of viscosity on pressure buildup can be ignored. The above sensitivity analysis shows that to reduce the buildup of pressure with time, a reservoir should have high permeability, large porosity, and large matrix compressibility. The injected liquid should have large compressibility, small viscosity, and small density.

\section{Estimation of Injection Volume and Rate}

The injection volume was estimated using equation (3). Whereas this equation shows that the final injection volume depends only on the size of the reservoir, storage capacity, and maximum allowable increase in pressure, the actual injection process is also controlled by the permeability of the reservoir.

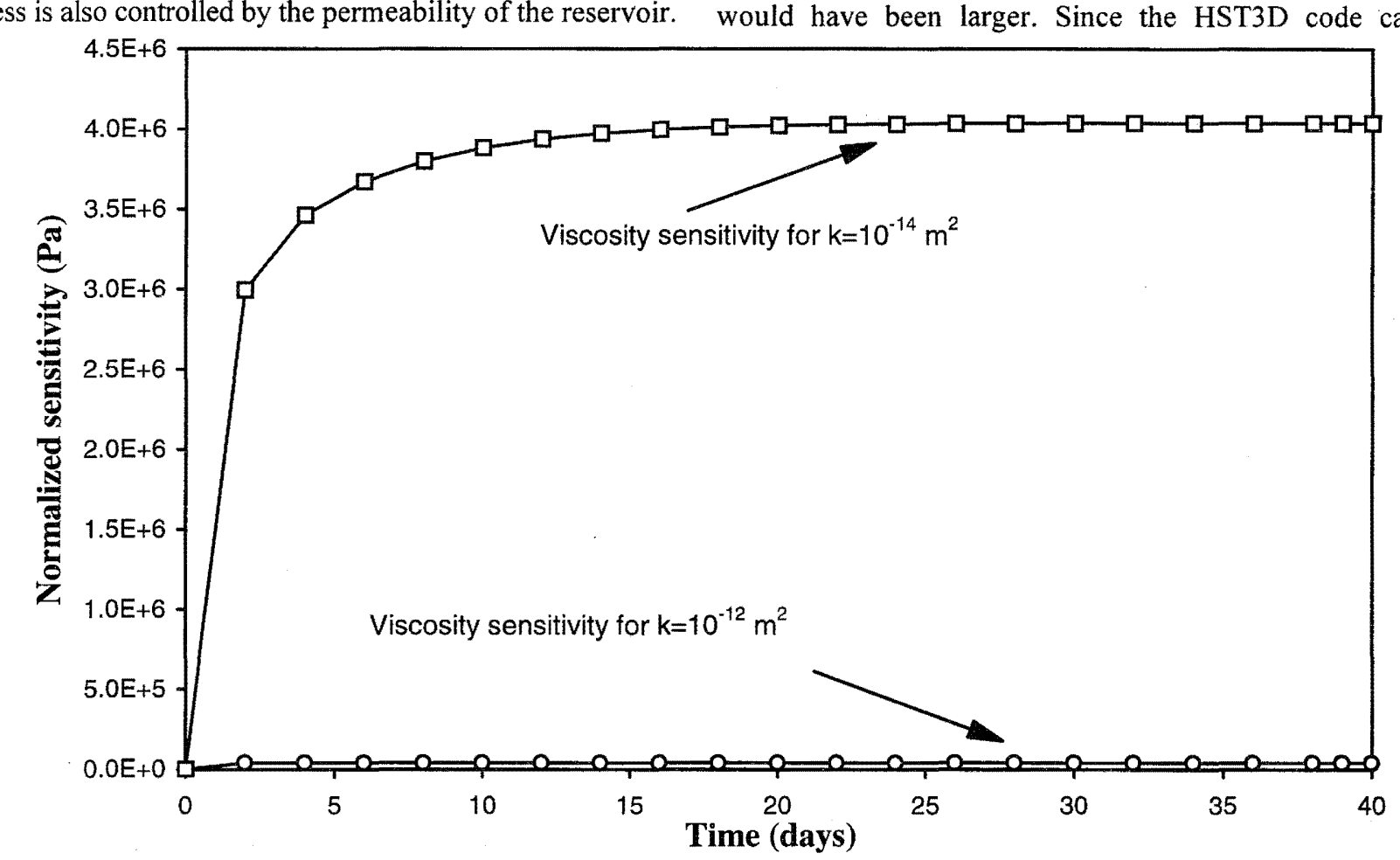

Figure 11. Relation between 1) normalized sensitivity of pressure to viscosity, and 2) injection time.
The numerical simulator HST3D was used here to simulate the injection process and to estimate the injection volume and rate.

When the injection rate is $5,000 \mathrm{~m}^{3} / \mathrm{d}$, after 330 days the pressure at the injection well near the top of the reservoir reaches $7.91 \times 10^{6} \mathrm{~Pa}$. This value is very similar to the pressure limit. The corresponding liquid injected is equal to $5,000 \times 330$ $=1.65 \times 106 \mathrm{~m}^{3}$, which is very similar to the amount estimated using equation (3).

The above injection volume is for reservoir permeability $k=5 \times 10^{-13} \mathrm{~m}^{2}$. For the same reservoir, if the permeability is $5 \times 10^{-14} \mathrm{~m}^{2}$, the injected water cannot easily transmit laterally. At the injection rate of $5,000 \mathrm{~m}^{3} / \mathrm{d}$, the pressure in the injection well reaches $8.00 \times 10^{6} \mathrm{~Pa}$ very quickly. In order to reduce the speed of pressure build-up near the injection well, the injection rate has to be very small. For example, when the injection rate is $1,000 \mathrm{~m}^{3} / \mathrm{d}$, after 1,240 days, the pressure is $7.98 \times 10^{6} \mathrm{~Pa}$, and the total injection volume is about $1.24 \times 10^{6} \mathrm{~m}^{3}$. This result shows that the permeability, in addition to the total storage capacity, is highly significant in identifying a realistic reservoir for liquid waste disposal. The spatial distribution of the permeability should be investigated carefully before injection wells are installed. Since the pressure can be built up most quickly near the injection wells, they should be sited where the reservoir has relatively high permeability.

The volume quantity discussed above is a conservative estimate. When the pressure near the injection well is increased to $8.00 \times 10^{6} \mathrm{~Pa}$, it is assumed that the maximum injection volume is reached. However, the pressure in the reservoir as a whole is still less than the limit. By using a smaller injection rate or injection-recovery-injection procedures, the pressure can disseminate laterally and more liquid can be injected. In addition, if gas had been considered, the volume of injection would have been larger. Since the HST3D code cannot

Hydrogeology Journal, v. 5, no. 3, 1997 
simulate a reservoir filled with gas, the estimation based on HST3D is a minimum. To provide a more accurate estimation of the injection volume in the presence of both gas and brine, a model of multiphase flow and transport is required.

Pressure and Concentration Distributions after Injection Although it is assumed that the reservoir is still underpressured at the end of injection, a prediction is needed of the pressure changes over time after injection and when the pressure becomes hydrostatic. The migration of injected wastes was also predicted to see if the waste would be contained to prevent contamination of the shallow aquifer for an operationally permanent time period. Because the pressure and concentration near the injection well are most significant, the vertical distributions of pressure head and concentration at $r=5.3 \mathrm{~m}$ are examined.

\section{Hydraulic head}

Figure 12 shows the relation between the vertical head profile at $5.3 \mathrm{~m}$ and time since injection. The head in the reservoir increases rapidly when waste is injected. During the injection period of 330 days, the head in the shale shows almost no response to the head change in the reservoir. At the beginning of the recovery period, the head near the injection well shows a rapid decline. After a long time; water in the upper aquifer gradually recharges to the reservoir. The process of recharge is extremely slow because of the ultra-low permeability of the shale formation. The response of the head in the shale can lag considerably behind the change of head in the reservoir by thousands of years. The reservoir is still underpressured even at 1 million years.

\section{Concentration}

Figure 13 shows the relation between the relative concentration $C / C_{0}$ at $r=5.3 \mathrm{~m}$ and time, where $C_{0}$ is concentration of injected chemical. For simplicity, the assumption is made that the background concentration is zero. In the reservoir, the concentration increases to maximum at the end of injection and then reduces very slowly with time. The concentration above the reservoir is extremely small and becomes virtually zero before time $=10,000$ years. Even after one million years, only in the shale directly above the reservoir does the concentration increase to about 0.6 (Fig. 13). The concentration in the rest of the shale formation is still almost zero. This result shows that as long as the reservoir is underpressured, the vertical migration of contaminants is dominated by molecular diffusion, and that no upward advection occurs. Therefore, the vertical migration is not significant and the wastes can be stored safely for a permanently for all practical purposes.

\section{Summary and Future Studies}

This paper presents the results of analysis of a hypothetical underpressured reservoir for liquid waste disposal, based on the geologic setting of the Hugoton field in the southwestern United States. The poor vertical communication through the geologic formations with extremely low permeability makes a setting such as the Hugoton reservoir a potential site for waste disposal. The subnormal pressure in the reservoir is likely to prevent the waste from contaminating the shallow aquifer for a practically permanent time.

The sensitivities of the model to aquifer and flow parameters were analyzed to gain insights into the physical factors controlling the pressure buildup and disposal volume.

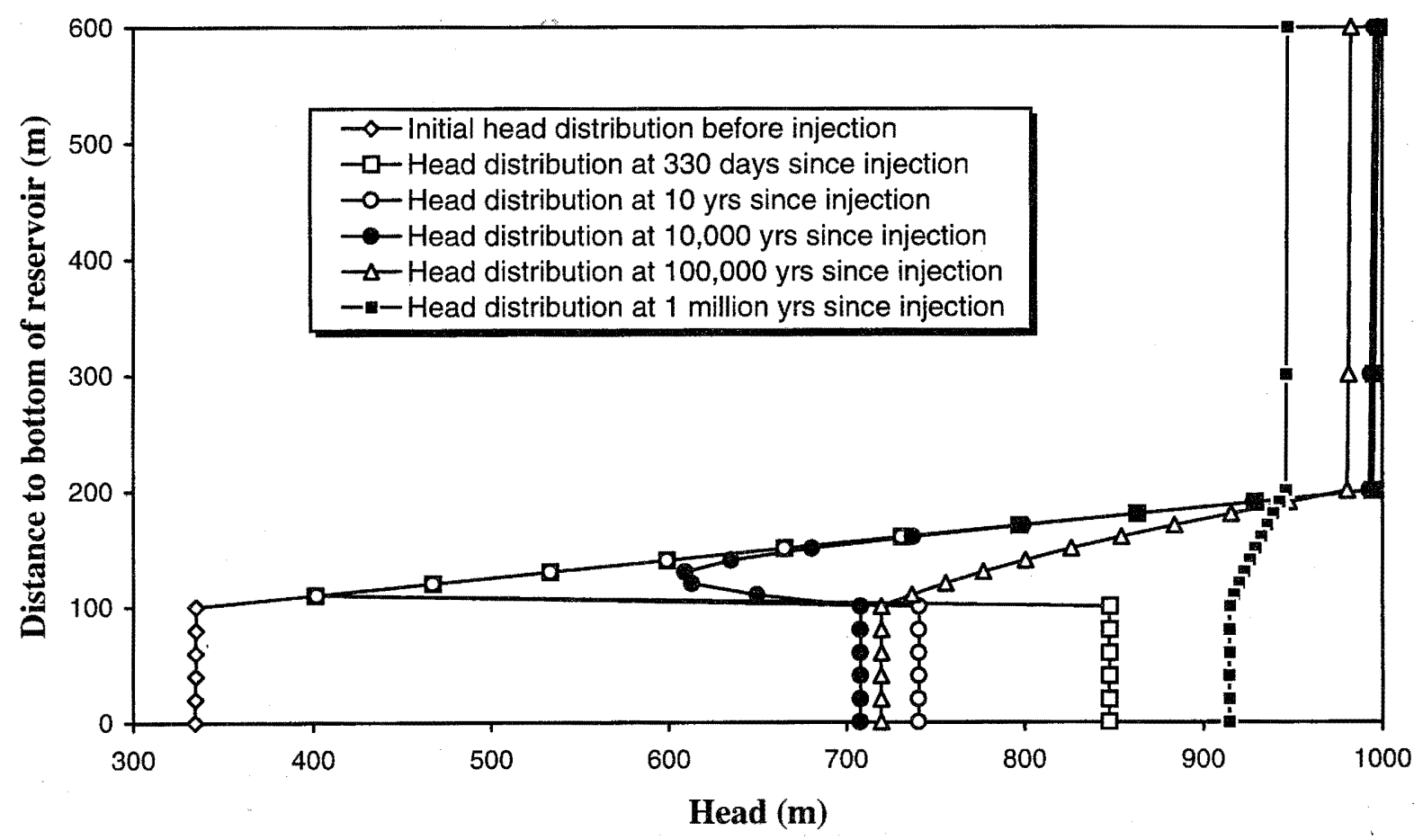

Figure 12. Relation between distance to bottom of reservoir and head for various times since injection began. 


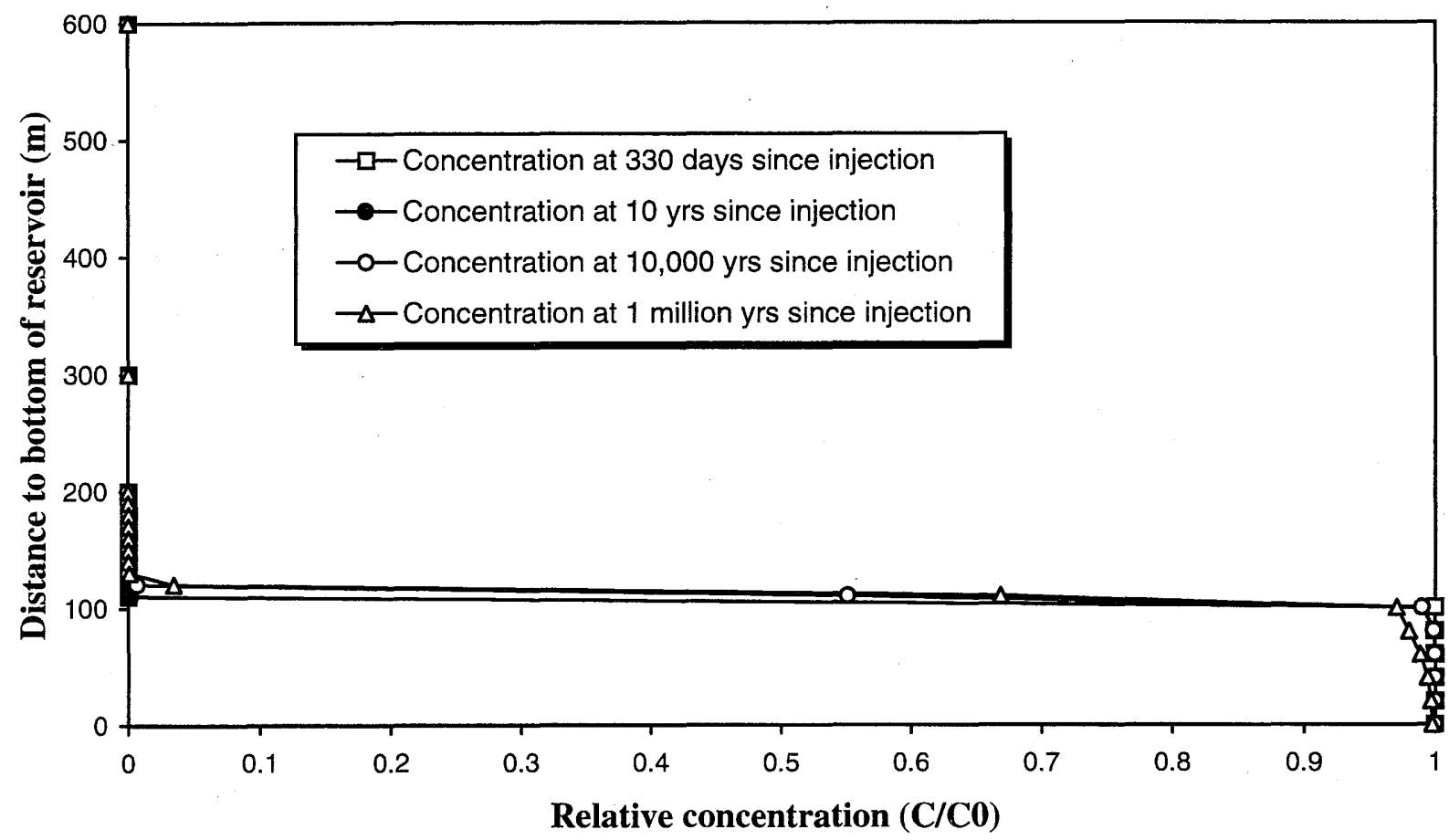

Figure 13. Relation between distance to bottom of reservoir and relative concentration for various times since injection began.

The theoretical maximum injection volume depends only on the size of the reservoir, storage capacity, and maximum allowable increase in pressure, but the actual injection process also depends on the permeability of the reservoir. Permeability is the key parameter and the sensitivity behavior of many other parameters depends on the magnitude of permeability. Pressure is very sensitive to porosity and matrix and fluid compressibilities only when the permeability is large. The viscosity is a factor of importance only when the permeability is small. For a reservoir of large permeability, the influence of viscosity on pressure buildup can be ignored. To reduce the buildup of pressure with time, a reservoir should have large permeability, large porosity, and large matrix compressibility. The injected liquid should have large compressibility, small viscosity, and small density.

The vertical concentration and hydraulic-head distributions in response to waste injection were simulated using the numerical code HST3D. The maximum safe disposal volume was estimated under the restrictive conditions that underpressurization persists after injection, and that the migration of the waste is restricted to prevent contamination of the neighboring aquifers for a practically permanent time period. The estimated volume to be disposed of in a single well is at least $1.65 \times 10^{6} \mathrm{~m}^{3}$.

An attempt was made to estimate the permeability of the Wellington Shale. The permeability value that leads to insignificant pressure change over 100 years is assumed to be the maximum value of the shale permeability. This value is estimated to be $1 \times 10^{-20} \mathrm{~m}^{2}$. If the permeability of the shale were small enough to keep the reservoir underpressured, the waste should be contained safely within the reservoir. Numerical simulation shows that, after injection, the reservoir remains underpressured for 0.5 million years and the contaminants remain in the reservoir or near the bottom of the shale for one million years. These estimates are probably conservative because the actual value of the shale permeability could be even smaller than $1 \times 10^{-20} \mathrm{~m}^{2}$, and the model ignores the influence of layers of small permeability within the reservoir.

The emphasis of this paper is on the vertical distribution of pressure and concentration in response to injection. The basic ideas and procedures used here could be extended to a threedimensional model for a more realistic representation of the hydrogeologic and geochemical conditions. In future studies, the mechanisms of subnormal pressure and the gas-brine multiphase effects should be addressed.

\section{Acknowledgments}

This research was supported by the School of Mines and Energy Development at the University of Alabama. The authors are very grateful to John Bradley and David Powley for their invaluable advice and assistance. Thanks also go to Kenneth Kipp, Jr., for providing the most recent version of the HST3D code along with many helpful suggestions and comments, and to Mark Person for his constructive review comments. 


\section{References}

Adler, F. J., 1971, Future petroleum provinces of the Mid-Continent, Region 7, in Cram, L.H., ed., Future petroleum provinces of the United States - Their geology and potential: American Association of Petroleum Geologists Memoir 15, p. 985-1042.

Barker, C., 1987, Development of abnormal and subnormal pressured in reservoirs containing bacterially generated gas: American Association of Petroleum Geologists Bulletin, v. 71, p. 1404-1413.

Beck, J.V., and Arnold, K.J., 1977, Parameter estimation in engineering and science: New York, John Wiley and Sons, $501 \mathrm{p}$.

Belitz, K., and Bredehoeft, J.D., 1986, Comment on "Safe disposal of toxic radioactive liquid wastes": Geology, v. 14, p. 266-267.

1988, Hydrodynamics of Denver Basin: Explanation of subnormal fluid pressures: American Association of Petroleum Geologists Bulletin, v. 72, p. 1334-1359.

Bradley, J., 1985, Safe disposal of toxic and radioactive liquid wastes: Geology, v. 13, p. 328-329.

Bradley J.S., and Powley, D.E., 1995, Pressure reservoirs in sedimentary basins: a review, in Ortoleva, P. J., ed., Basin compartments and seals: American Association of Petroleum Geologists Memoir 61, p. 3-26.

Bredehoeft, J.D., and Hanshaw, B.B., 1968, On the maintenance of anomalous fluid pressures; $I$, Thick sedimentary sequences: Geological Society of America Bulletin, v. 79, no. 9, p. 1097-1106.

Corbet, T., and Bethke, C.M., 1992, Dissequilibrium fluid pressures and groundwater flow in the Western Canada sedimentary basin: Journal of Geophysical Research, v. 97, p. 7203-7217.

DeVries, R.N., and Kent, D.C., 1973, Sensitivity of groundwater flow models to vertical variability of aquifer constants: Water Resources Bulletin, v. 9, no. 5, p. 998-1005.

Dickey, P.A., and Cox, W.C., 1977, Oil and gas in reservoirs with subnormal pressures: American Association of Petroleum Geologists Bulletin, v. 61, p. 2134-2142.

Ebbs, D.J., Jr., Works, A.M., and Fetkovich, M.J., 1990, A field case study of replacement well analysis: Guymon-Hugoton Field, Oklahoma, in Society of Petroleum Engineers Annual Technical Conference, 65th, New Orleans, LA, 1990: Paper SPE 20755, p. $387-400$.

Ferran, L. H., 1973, Evaluation of abnormally high and low pressured, Morrow Sands in northwestern Oklahoma using well logs and water sample data: Tulsa, OK, University of Tulsa Master Thesis, $110 \mathrm{p}$.

Freeze, R.A., and Cherry, J.A., 1979, Groundwater: New Jersey, Prentice-Hall, $604 \mathrm{p}$.

Garlough, J.H., and Taylor, G.L., 1941, Hugoton gas field, Grant, Haskell, Morton, Stevens, and Seward Counties, Kansas, and Texas County, Oklahoma, in Levorsen, A. I., ed., Stratigraphic type of oil fields: The American Association of Petroleum Geologists, $p$. 78-104.

Hunt, J.R., 1990, Generation and migration of petroleum from abnormally pressured fluid reservoirs: American Association of Petroleum Geologists Bulletin, v. 74, no. 1, p. 1-12.
Keith, L. A., and Rimstidt, J.D., 1985, A numerical compaction model of overpressuring in shales: Mathematical Geology, v. 17, no. 2, p. 115-135.

Kipp, K.L., Jr., 1987, HST3D: A computer code for simulation of the heat and solute transport in three-dimensional ground-water flow systems: U.S. Geological Survey Water Resources Investigation Report 86-4095, Denver, Colorado, 517 p.

LaMoreaux, P.E., and Vrba, J., 1990, Hydrogeology and management of hazardous waste by deep-well disposal: International Contributions to Hydrogeology, v. 10, Verlag Heinz Heise, Hannover, Germany, $267 \mathrm{p}$.

Neuzil, C.E, 1986, Groundwater flow in low-permeability environments: Water Resources Research, v. 22, no. 8., p. 1163-1195.

Neuzil, C.E., 1995, Abnormal pressures as hydrodynamic phenomena: American Journal of Sciences, v. 295, p. 742-786.

Neuzil, C.E., and Pollock, D.W., 1983, Erosional unloading and fluid pressures in hydraulically "tight" rocks: Journal of Geology, v. 91, p. 179-193.

Mason, J.W., 1968, Hugoton Panhandle Field, Kansas, Oklahoma, Texas, in Beebe, B.W. ed., Natural gases of North America: American Association of Petroleum Geologists Memoir 9, v. 2, p. 1539-1547.

McElwee, C.D, 1987, Sensitivity analysis of groundwater models, in Bear J., and Corapcioglu, M.Y,, eds., Advances in transport phenomena in porous media: NATO Advanced Study Institute Series, Series E, v. 128, p. 751-817.

Ortoleva, P.J., ed., 1995, Basin compartments and seals: American Association of Petroleum Geologists Memoir 61, $477 \mathrm{p}$.

Ortoleva, P.J., Al-Shaieb, Z., and Puckette, J., 1995, Genesis and dynamics of basin reservoirs and seal: American Joumal of Science, v. 295 , p. $345-427$.

Pippin, L., 1968, Panhandle-Hugoton field, Texas-Oklahoma-Kansas, the first fifty years: American Association of Petroleum Geologists Memoir 14, p. 204-222.

Russell, W.L., 1972, Pressure-depth relations in Appalachian region: American Association of Petroleum Geologists Bulletin, v. 56, no. 3, p. 528-536.

Senger, R.K., and Fogg, G.E., 1987, Regional underpressuring in deep brine aquifers, Palo Duro Basin, Texas: Water Resources Research, v. 23 , no. 8 , p. 1481-1507.

Siemers, W.T., and Ahr, W.M., 1990, Reservoir facies, pore characteristics, and flow units: Lower Permian Chase Group, Guymon-Hugoton Field, Oklahoma, in Society of Petroleum Engineers Annual Technical Conference, 65th, New Orleans, LA: 1990, Paper SPE 20757, p. 413-423.

Received, February 1996

Revised, October 1996; March 1997

Accepted, May 1997 